\title{
Pengaruh Social Influence Terhadap Behavioral Intention Penggunaan Marketplace Pada Umkm Di Kota Bandung
}

\author{
Nurhalimah \\ Mahasiswa Program Studi Administrasi Bisnis \\ Universitas Sangga Buana YPKP Bandung \\ Nurhalimah5370@gmail.com
}

\begin{abstract}
ABSTRAK
Tujuan dari penelitian ini adalah untuk mengetahui pengaruh social influence (Pengaruh Sosial) terhadap behavioral intentions (minat pemanfaatan) pengguna Marketplace di Kota Bandung. Penelitian ini menggunakan teori Model Unified Theory of Acceptance and use of Technology (UTAUT). Metode pengumpulan data yang digunakan dalam penelitian ini dilakukan dengan cara menyebarkan kuesioner pada 400 orang UMKM yang telah menggunakan aplikasi Marketplace. Penelitian ini menggunakan pendekatan Kuantitatif dengan medote asosiatif kasual yaitu metode yang digunakan untuk mengetahui ada dan tidaknya pengaruh variabel bebas terhadap variabel terikat, teknik analisis data menggunakan Metode statistic Multivariate Structural Equation Model (SEM). Berdasarkan penelitian ini variabel dependen dipengaruhi oleh variabel independen. Hasil penelitian ini menunjukan Pengaruh Social Influence terhadap Behavioral Intention penggunaan Marketplace pada UMKM di Kota Bandung yaitu sebesar 0.897 dan dari semua variabel independen mempunyai pengaruh secara simultan terhadap variabel dependen sebesar 173.596. Pengguna Marketplace perlu lebih meningkatkan sosialisasi kepada masyarakat khususnya UMKM dan memberikan pemahaman bahwa dengan menggunakn Marketplace dapat lebih meningkatkan bisnis mereka.
\end{abstract}

Kata Kunci: Pengaruh sosial, Minat Pemanfaatan, UMKM, dan Marketplace

\section{ABSTRACT}

The aim of this study is to determine the effect of social influence on the behavioral intentions (interest in utilization) of Marketplace users in Bandung. This study uses the theory of the Unified Theory of Acceptance and use of Technology (UTAUT) theory. The data collection method used in this study was carried out by distributing questionnaires to 400 MSMEs who had used the Marketplace application. This study uses a quantitative approach with a casual associative method which is the method used to determine whether there is an influence of independent variables on the dependent variable, the data analysis technique uses the Statistical Method of Multivariate Structural Equation Model (SEM). Based on this study the dependent variable is influenced by the independent variable. The results of this study indicate the influence of social influences on the Behavioral Intention of using Marketplace at MSMEs in Bandung in the amount of 0.897 and of all the independent variables have a simultaneous influence on the dependent variable of 173,596. Marketplace users need to further improve socialization to the public, especially MSMEs and provide understanding that using Marketplace can further enhance their business.

Keywords: Social influence, Utilization Interest, MSME, and Marketplace 


\section{PENDAHULUAN}

Perkembangan Teknologi yang semakin pesat tidak hanya mengubah cara berkomunikasi masyarakat, namun juga metode perdagangannya. Di mana banyak bermunculan e-commerce yang berguna untuk jadi tempat jual-beli barang secara online yang bisa digunakan oleh pengusaha. Kesempatan ini pun tidak luput dilewatkan oleh para UMKM, dimana marketplace untuk UMKM ini mesti dimanfaatkan oleh pemilik usaha mikro, kecil dan menengah. Pasalnya selama ini kendala yang selalu dihadapi oleh UMKM adalah masalah pemasaran. Dengan adanya e-commerce dan marketplace menjadi kesempatan bagi mereka karena dengan menggunakan marketplace ataupun e-commerce kemungkinan pasar mereka akan lebih luas dan promosi pun jauh lebih murah.

Dilihat dari tingginya pertumbuhan dan jumlah UMKM di Indonesia, Bandung merupakan salah satu kota yang memiliki jumlah UMKM yang tinggi. Menurut Badan Pusat Statistik (BPS) Kota Bandung pada tahun 2018, memiliki jumlah penduduk sebanyak 2.490.622 jiwa dengan jumlah UMKM pada tahun 2017 sekitar 300.000.

Dengan tingginya pertumbuhan dan jumlah UMKM di kota Bandung maka dari itu pemerintah kota Bandung ikut mendukung setiap inovasi yang dapat mendorong perkembangan usaha kecil, menengah dan mikro (UMKM). Sumber: Bisnis.com.

Bentuk upaya Pemerintah dalam mendukung UMKM agar selalu terus berkembang bersamaan dengan kemajuan teknologi, maka dari itu salah satu bentuk teknologi ideal yang mendukung UMKM untuk memasuki pasar online adalah Marketplace. Marketplace membuka kesempatan bagi semua orang baik itu perusahaan besar ataupun UMKM untuk berjualan secara online.

Adapun gambaran Marketplace di Benua Asia lainnya yang menggunakan Marketplace salah satunya adalah
Indonesia dan dapat dilihat dari gambar sebagai berikut:

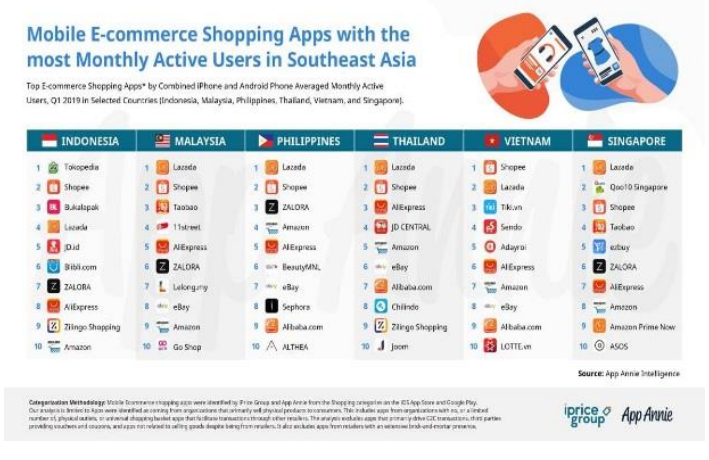

Sumber : iprice group (2019)

Gambar 2 : Hasil Survei pada Tahun 2019 Tentang Aplikasi Belanja e-commerce Seluler dengan Pengguna Aktif Bulanan di Asia Tenggara. Aplikasi belanja teratas

Adapun 5 Marketplace Terbaik di Indonesia yaitu:

1. Tokopedia

2. Shopee

3. Bukalapak

4. Lazada

5. JD.id

Kehadiran website Marketplace sebagai tempat jual beli secara online, membawa solusi bagi UMKM dalam memperbaiki pemasaran dan memperluas pangsa pasarnya. Adapun website Marketplace di Indonesia yang mampu di manfaatkan untuk melakukan jual beli online antara lain: Tokopedia, Shopee, Bukalapak, Lazada, JD.id. Berdasarkan latar belakang diatas maka tujuan penelitian ini adalah untuk mengetahui Pengaruh Social Influence Terhadap Behavioral Intention Penggunaan Marketplace Pada Umkm Di Kota Bandung.

\section{TINJAUAN PUSTAKA}

\section{Pemasaran}

Peranan strategi pemasaran ialah mencangkup setiap usaha untuk mencapai kesesuaian antara perusahaan dengan lingkungan dalam rangka memenuhi target pasar. Menurut Kotler \& Keller (2016:29) pemasaran adalah proses dimana perusahaan menciptakan nilai dari sebuah produk. Kotler \& Keller (2016:5) 
mendefinisikan bahwa pemasaran adalah sebuah proses kemasyarakatan dimana individu dan kelompok memperoleh apa yang mereka butuhkan dan ingin menciptakan dengan menciptakan, menawarkann, dan secara bebas mempertukarkan produk dan jasa yang bernilai dengan orang lain.

Menurut Kotler dan Keller (2016:5) manajemen pemasaran adalah sebagai seni dan ilmu memilih pasar sasaran dan meraih, memepertahankan serta menumbuhkan pelanggan dengan menciptakan, menghantarkan dan mengkomunikasikan nilai pelanggan yang unggul.

\section{Unified Theory of Acceptance and Use of Thechnology (UTAUT)}

Model Unified Theory of Acceptance and Use of Thechnology (UTAUT) merupakan teori yang berpengaruh dan banyak diadopsi untuk melakukan penelitian penerimaan pengguna (user acceptance) terhadap suatu teknologi informasi. UTAUT yang dikembangkan oleh Venkatesh, et al.,(2003:446) menggabungkan fitur-fitur yang berhasil dari delapan teori penerimaan teknologi terkemuka menjadi satu teori. Adapun kedelapan teori terkemuka yang disatukan di dalam UTAUT adalah :

1) Theory of Reasoned Action (TRA)

2) Technology Acceptance Model (TAM)

3) Motivational Model (MM)

4) Theory of Planned Behavior (TPB)

5) Combined TAM and TPB (CTAM-TPB)

6) Model of PC Utilization (MPCU)

7) Innovation Diffusion Theory (IDT)

8) Social Cognitive Theory (SCT)

Selain dari 8 teori di atas UTAUT memiliki empat kontruk yang mempengaruhi Minat Pemanfaatan (behavioral intention) ke penggunaan teknologi (use a technology). Empat kontruk tersebut terdiri dari :

1) Ekspektasi kinerja (performance expectancy)
2) Ekspektasi usaha (effort expectancy)

3) Pengaruh sosial (social influence)

4) Kondisi pendukung (facilitating conditions)

Empat (4) konstruk diatas dapat digambarkan dalam gambar berikut ini :

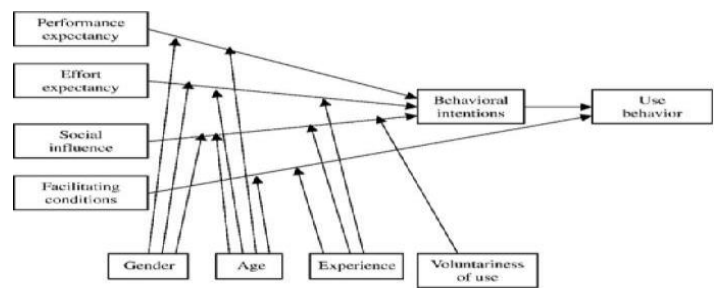

Gambar 2 : Kerangka Model UTAUT

Sumber : Vankatesh, et al.,(2003)

Dalam konsep ini terdapat gabungan variabel-variabel yang diperoleh dari model penelitian sebelumnya tentang model penerimaan dan penggunaan teknologi. Adapun variabel tersebut adalah :

1) Norma Subyektif (Subjective norms)

2) Faktor-faktor sosial (Social Factors)

3) Gambaran (image)

\section{Minat Pemanfaatan}

Minat pemanfaatan teknologi informasi (behavioral intention) didefinisikan sebagai tingkat keinginan atau niat pemakai menggunakan sistem secara terus menerus dengan asumsi bahwa mereka mempunyai akses terhadap informasi. Seorang akan berminat menggunakan suatu teknologi informasi yang baru apabila si pengguna tersebut meyakini dengan mennggunakan teknologi informasi tersebut akan meningkatkan kinerjanya, menggunakan teknologi informasi dapat dilakukan dengan mudah, dan si pengguna tersebut mendapatkan pengaruh lingkungan sekitarnya dalam menggunakan teknologi informasi tersebut.

Desktripsi singkat tentang sistem perilaku Icek Ajzen (2013) merumuskan sebuah teori. Menurut teori tersebut, perilaku manusia dipandu oleh tiga 
macam pertimbangan: keyakinan tentang konsekuensi yang mungkin timbul dari perilaku (behavioural beliefs), keyakinan tentang harapan normatif orang lain (normative beliefs), dan keyakinan tentang keberadaan faktor-faktor yang dapat memfasilitasi atau menghambat kinerja perilaku (control beliefs).

\section{Usaha Mikro, Kecil dan Menengah (UMKM)}

Menurut UU No. 20 Tahun 2008

Pasal 1 tentang UMKM disebutkan bahwa:

1) Usaha Mikro adalah usaha produktif milik orang perorangan dan atau badan usaha perorangan yang memenuhi kriteria usaha mikro sebagaimana diatur dalam undangundang ini.

2) Usaha Kecil adalah usaha ekonomi produktif yang berdiri sendiri, yang dilakukan oleh orang perorangan atau badan usaha yang bukan anak perusahaan atau cabang perusahaan yang dimiliki, dikuasai, atau menjadi bagian baik langsung maupun tidak langsung dari usaha menengah atau usaha besar yang memenuhi kriteria usaha kecil sebagaimana dimaksud dalam undang - undang ini.

3) Usaha Menengah adalah usaha ekonomi produktif yang berdiri sendiri, yang dilakukan oleh orang perorangan atau badan usaha yang bukan anak perusahaan atau cabang yang dimiliki, dikuasai, atau menjadi bagian langsung maupun tidak langsung dengan Usaha Kecil atau Usaha Besar dengan jumlah kekayaan yang bersih atau hasil penjualan tahunan sebagaimana diatur dalam undang - undang ini.

\section{Marketplace}

Marketplace adalah sebuah lokasi jual beli produk dimana seller dan juga konsumen bertemu disuatu tempat. Seller akan menjual barangnya di lapak yang sudah disediakan oleh e-commerce dengan konsep marketplace. Barang yang dijual di marketplace tersebut kemudian akan diiklankan oleh pihak e-commerce untuk mendapatkan konsumen yang potensial. Selain itu marketplace juga sebuah aplikasi atau situs web yang memberi fasilitas jual beli online dari berbagai sumber. Pemilik situs web atau aplikasi tidak memiliki produk apapun dan bisnis mereka hanya menyajikan produk orang lain kepada pengguna kemudian memfasilitasinya. Marketplace merupakan bagian dari e-commerce, marketplace biasanya mempunyai system tersendiri yang dapat mengatur ratusan bahkan jutaan produk yang ingin dijual maupun dibeli.

\section{Kerangka Pemikiran}

Thompson et al. (1991) menemukan hubungan yang positif dan signifikan antara faktor-faktor sosial pemakai sistem, dimana faktor-faktor sosial ditunjukkan dari besarnya dukungan teman kerja, manajer senior, pimpinan dan organisasi. Sedangkan Davis et al. (1989) menunjukkan tidak ada hubungan yang signifikan norma-norma sosial terhadap pemanfaatan sistem informasi.

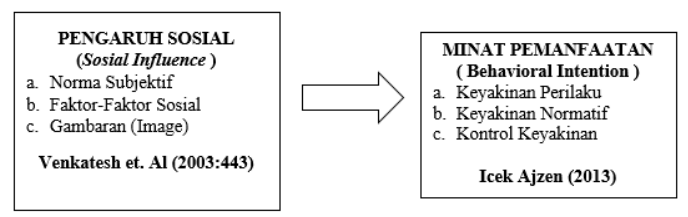

Gambar 3 : Kerangka Pemikiran

\section{Hipotesis}

Berdasarkan identifikasi masalah dan kerangka pemikiran yang telah diuraikan pada bab dan sub bab sebelumnya, peneliti mengajukan hipotesis sebagai berikut :

$\mathrm{H}_{1}$ : Social Influence (Pengaruh Sosial) berpengaruh terhadap behavioral intention (Minat Pemanfaatan) penggunaan marketplace pada UMKM di Bandung.

$\mathrm{H}_{0}$ : Behavioral Intention (Minat Pemanfaatan) berpengaruh terhadap penggunaan marketplace di Bandung. 


\section{METODOLOGI}

Menurut Sugiyono (2017:80) mendefinisikan Populasi adalah sebagai berikut: "Dalam penelitian kuantitatif populasi adalah wilayah generalisasi yang terdiri atas : objek atau subjek yang mempunyai kuantitas dan karakteristik tertentu yang ditetapkan oleh peneliti untuk dipelajari dan kemudian ditarik kesimpulannya."

Tabel 1 : Jumlah Populasi Marketplace di Kota Bandung

\begin{tabular}{|c|c|}
\hline Jenis Marketplace & Populasi \\
\hline Sokopedia & 390.463 \\
\hline S Shopee & 356.480 \\
\hline Bukalapak & 186.758 \\
\hline LAZADA & 70.355 \\
\hline JD.10 & 55.336 \\
\hline Jumlah & 1.059 .392 \\
\hline
\end{tabular}

Pada penelitian ini teknik pengambilan sampel menggunakan rumus Slovin sebagai berikut :

$$
\mathrm{n}=\frac{N}{1+N e^{2}}
$$

Keterangan:

n: Sampel

$N$ : Populasi

e: Taraf kesalahan atau nilai kritis

Berdasarkan rumus tersebut maka jumlah sampel yang diambil dalam penelitian ini adalah :

$$
\begin{gathered}
\text { Jadi } N=\frac{1,059,392}{1+1,059,392\left(0,05^{2}\right)} \\
=399,84
\end{gathered}
$$

Jadi jumlah sampel yang akan diambil dalam penelitian ini adalah 399,84 dan dibulatkan menjadi 400 sampel.

Karena data awal yang digunakan dalam penelitian ini skalanya masih skala ordinal, maka peneliti menggunakan MSI untuk mengubah skala ordinal menjadi skala interval. Menurut Riduwan dan Kuncoro (2011:30) menstransformasikan data ordinal menjadi data interval gunanya untuk memenuhi sebagian dari syarat analisis parametrik yang mana data minemal interval. Teknik transformasi yang paling sederhana dengan menggunakan MSI (Method of Successive Interval).

\section{HASIL DAN PEMBAHASAN}

\section{Partial Lest Square (PLS)}

Menurut Ananda (2015:18) Analisis pada smartpls dilakukan dengan tiga tahap yaitu: Analisa Outer Model, Analisa Inner Model dan Pengujian Hipotesa. Analisis outer model dilakukan untuk memastikan bahwa measurement yang digunakan layak untuk dijadikan pengukuran (valid dan reliable). Analisa outer model dapat dilihat dari beberapa indikator:

Tabel 2 : Convergent validity

\begin{tabular}{lll}
\hline & BI & SI \\
\hline X1 & & 0.620 \\
X2 & & 0.622 \\
X3 & & 0.814 \\
X4 & & 0.869 \\
X5 & & 0.632 \\
X6 & & 0.849 \\
X7 & & 0.920 \\
X8 & & 0.782 \\
X9 & & 0.840 \\
Y1 & 0.709 & \\
Y2 & 0.928 & \\
Y3 & 0.909 & \\
Y4 & 0.838 & \\
Y5 & 0.746 & \\
Y6 & 0.931 & \\
Y7 & 0.912 & \\
\hline
\end{tabular}

Sumber : Hasil Output SmartPLS

Dilihat dari tabel diatas menunjukan bahwa nilai indikator variabel dari masingmasing mempunyai nilai diatas 0,70 dan ada 3 indikator variabel yang nilainya di bawah nilai 0,70 nilai tersebut masih bisa ditolerir karena outer loading dapat ditorerir jika nilai lebih dari 0,50 maka semua indikator mempunyai nilai realibilitas yang baik.

Berdasarkan tabel 3 bahwa nilai loading Behavioral Intention (BI) lebih besar yaitu $(\mathrm{Y} 1=0.709, \mathrm{Y} 2=0,928, \mathrm{Y} 3=0,909, \mathrm{Y} 4=$ $0,838, \mathrm{Y} 5=0,746, \mathrm{Y} 6=0,931, \mathrm{Y} 7=0,912$ ) dari nilai loading konstruk yang lainnya, maka hasil analisa cross loading tampak bahwa tidak terjadi permasalahan discriminat validity. 
Tabel 3: Discriminant validity

\begin{tabular}{rrr}
\hline & \multicolumn{1}{c}{ BI } & \multicolumn{1}{l}{ SI } \\
\hline X1 & 0.616 & 0.620 \\
X2 & 0.680 & 0.622 \\
X3 & 0.770 & 0.814 \\
X4 & 0.736 & 0.869 \\
X5 & 0.634 & 0.632 \\
X6 & 0.711 & 0.849 \\
X7 & 0.874 & 0.920 \\
X8 & 0.745 & 0.782 \\
X9 & 0.763 & 0.840 \\
Y1 & 0.709 & 0.587 \\
Y2 & 0.928 & 0.903 \\
Y3 & 0.909 & 0.858 \\
Y4 & 0.838 & 0.826 \\
Y5 & 0.746 & 0.624 \\
Y6 & 0.931 & 0.899 \\
Y7 & 0.912 & 0.856 \\
\hline
\end{tabular}

Sumber : Hasil Output SmartPLS

Analisa inner model/analisa structural model dilakukan untuk memastikan bahwa model structural yang dibangun robust dan akurat. Evaluasi inner model dapat dilihat dari beberapa indikator yang meliputi :

Tabel 4 : Koefesien Determinasi $\left(\mathrm{R}^{2}\right)$

\begin{tabular}{lrr}
\hline & R Square & \multicolumn{2}{c}{$\begin{array}{l}\text { R Square } \\
\text { Adjusted }\end{array}$} \\
\hline BI & 0.879 & 0.879 \\
\hline
\end{tabular}

Sumber : Hasil Output SmartPLS

Dilihat dari tabel diatas nilai $\mathrm{R}^{2}$ atau $\mathrm{R}$ square bahwa nilai SI mempunyai pengaruh terhadap nilai BI, berikut adalah gambar Path $\mathrm{R}^{2}$ :

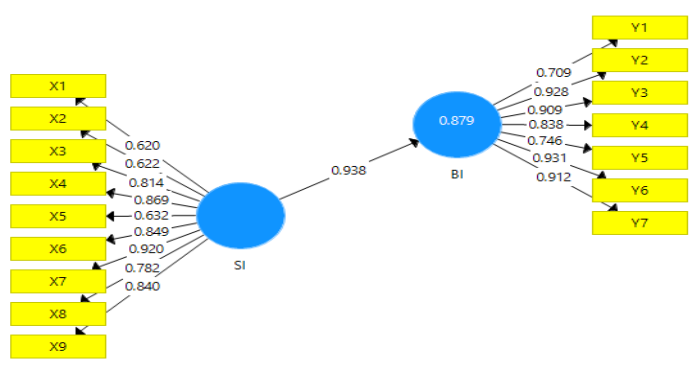

Gambar 4 : Output Diagram Jalur Dengan Smartpls

Gambar 4 menunjukan bahwa nilai SI terhadap nilai $\mathrm{BI}$ mempunyai pengaruh sebesar 0.879 .

\section{Goodnes of it (GOF)}

Berdasarkan data diatas dapat diketahui bahwa Q-square predictive relevance $\left(\mathrm{Q}^{2}\right)$ bernilai 0.879 atau $87.9 \%$. hal ini menunjukan bahwa BI (Behavioral Intention) mampu di jelaskan oleh pengaruh SI (Social Influence) sebesar $87.9 \%$.

\section{Hasil Uji Hipotesis}

Untuk pengujian hipotesa dilakukan dengan melihat nilai probabilitasnya dan t-statistiknya. Untuk nilai probabilitas, nilai p-value dengan alpha 5\% adalah kurang dari 0,05 . Nilai t-tabel untuk alpha $5 \%$ adalah 1,95. Sehingga kriteria penerimaan hipotesa adalah ketika $\mathrm{t}$ statistik > t-tabel. Pengujian Hipotesis dapat dilihat dalam tabel berikut:

Tabel 5: T-Statistik

\begin{tabular}{|c|c|c|r|r|r|r|}
\hline & $\begin{array}{c}\text { Original } \\
\text { Sample } \\
\text { (0) }\end{array}$ & $\begin{array}{c}\text { Sample } \\
\text { Mean } \\
\text { (M) }\end{array}$ & $\begin{array}{r}\text { Standard } \\
\text { Deviation } \\
\text { (STDEV) }\end{array}$ & $\begin{array}{r}\text { T Statistics } \\
\text { (IO/STDEV) }\end{array}$ & P Values & $\begin{array}{c}\text { Nilai T- } \\
\text { tabel }\end{array}$ \\
\hline $\mathrm{SI}>\mathrm{BI}$ & 0.938 & 0.938 & 0.005 & 173.596 & 0.000 & 1.985 \\
\hline
\end{tabular}

Sumber : Hasil Pengolahan SmartPLS

Kriteria pengujian menyatakan bahwa nilai T-Statistik lebih besar dari nilai kritis (t-tabel) maka dinyatakan adanya pengaruh variabel indevenden terhadap variabel dependen pada masingmasing hipotesis yang telah ditetapkan sebelumnya.

Berdasarkan hasil penelitian social influence, mempunyai pengaruh positif terhadap minat pemanfaatan (behavioral intention). Pada hasil pengujian yang tertera dalam tabel 5 dapat diketahui bahwa T-statistik antara pengaruh sosial (social influence) (X) berpengaruh terhadap minat pemanfaatan (behavioral intention) (Y) adalah 173.596 sedangkan nilai kritis (t-tabel) sebesar 1.985. hasil pengujian ini menunjukan bahwa pengaruh social (social influence) secara langsung berpengaruh terhadap minat pemanfaatan (Behavioral Intention). Dengan demikian Hipotesis H1 terpenuhi.

Pengaruh Social Influence terhadap Behavioral Intention penggunaan Marketplace pada UMKM di Kota Bandung yaitu sebesar 0.879, hasil pengujian ini menunjukan bahwa semua variabel independen berpengaruh terhadap variabel dependen. 
Jika dilihat dari hasil uji determinasi menjelaskan bahwa minat pengguna Marketplace dipengaruhi sebesar 87,9\%. Hal ini menjelaskan bahwa Pengaruh Social Influence terhadap Behavioral Intention penggunaan Marketplace pada UMKM di Kota Bandung dapat mempengaruhi minat beli konsumen online.

\section{KESIMPULAN}

Berdasarkan analisis hasil penelitian dan pembahasan, maka dapat disimpulkan sebagai berikut:

1. Pengaruh Sosial (Sosial Influence) (X) dapat di lihat di dalam variable Sosial Influence didapatkan hasil bahwa indikator faktor-faktor sosial secara umum, banyak UMKM telah mendukung penggunaan Marketplace ini menjadi indikator yang memiliki nilai rata-rata tertinggi sebesar 0,920 di bandingkan indikator-indikator lainnya pada variable Social influence.

2. Minat Pemanfaatan (Behavioral Intention) (Y) pada penelitian ini sangat berpengaruh terhadap Pengaruh Sosial (Social Influence) dapat di lihat di dalam variable Behavioral Intention didapatkan hasil bahwa indikator kontrol keyakinan yaitu bagi pengguna Marketplace dapat meningkatkan kinerja dalam berbisnis ini memiliki nilai rata-rata tertinggi yaitu sebesar 0,931 dibandingkan dengan indikatorindikator lain pada variable Behavioral Intention.

3. Jika dilihat dari hasil pengujian uji $\mathrm{f}$ diperoleh hasil estimasi f sebesar 7.279 dengan tingkat signifikansi sebesar 0,000 dan hasil uji determinasi menjelaskan bahwa minat pengguna Marketplace dipengaruhi sebesar $87,9 \%$.

Berdasarkan hasil penelitian maka peneliti memberikan saran seagai berikut:

1. Terus memanfaatkan aplikasi marketplace sehingga pengguna UMKM merasakan manfaat dari penggunaan marketplace yang dapat lebih meningkatkan bisnis para pengguna marketplace.

2. Penelitian selanjutnya dapat menambahkan variabel moderator dalam penelitian sesuai dengan model asli UTAUT, sehingga dapat menjelaskan lebih lanjut tentang penerapan model ini.

3. Ruang lingkup penelitian untuk penelitian selanjutnya dapat diperluas lagi sehingga tingkat generalisasi populasi lebih besar.

\section{DAFTAR PUSTAKA}

Ajzen, I.. (2013). Teori Perilaku yang Direncanakan Kuisioner. Database Instrumen Pengukuran untuk Ilmu Sosial. Diperoleh dari www.midss.ie

Alma, B. (2003). Manajemen Pemasaran dan Pemasaran Jasa. Edisi 2. Bandung: Alfabeta.

Bisnis.com (2019). Pemerintah Kota Bandung Dalam Mendukung UMKM di Jawa Barat. https://m.bisnis.com

Iprice group. (2019). Hasil Survei Pada Tahun 2019 Tentang Aplikasi Belanja E-Commerce Selluler Dengan Pengguna Aktif Bulanan di Asia Tenggara. https://ipricegroup.com

Jalaludin, Andi (2019). Analisis Pengelolaan Kualitas, Pendapatan Harga dan Promosi Produk Barang dan Jasa di UMKM Kelurahan Pasirlayung Kota Bandung. Universitas Sangga Buana YPKP. Bandung.

Jatmico Jati, Nugroho (2012). Analisis Faktor-Faktor yang Mempengaruhi Minat Pemanfaatan dan Penggunaan Sistem E-Ticket. Pada Universitas Diponegoro Semarang.

Jogiyanto. (2007). Sistem Informasi Keperilakuan. Yogyakarta: ANDI 
Kotler \& Keller. (2016:29). Manajemen Pemasaran Edisi 13 Jilid 1. Jakarta: Erlangga.

Marketplace. bdg (2018). Data Statistik Pengguna Marketplace di KotaBandung https://sp99712.sitebeat.com

Masyita Sari, Rizki (2018). Analisis Faktor-Faktor Yang Mempengaruhi Penggunaan Internet Terhadap Peningkatan Kinerja UKM Menggunakan Metode Structural Equation Modelling.

Nurzamzam, Devina (2018). Analisis Faktor-Faktor yang Mempengaruhi Permintaan Produk Pakaian Melalui E-Commerce. Pada Universitas Pendidikan Indonesia (UPI).

Putu Lestara P, Gusi (2019). Pengaruh Hedonic Motivation, Social Influence dan Perceived Enjoyment Terhadap penggunaan Marketplace Pada UMKM di Bali. pada Universitas Pendidikan Nasional (UNDIKNAS) Denpasar:

http://journal.undiknas.ac.id/index.ph p/manajemen

Susilowati (2018). Faktor-Faktor Yang Mempengaruhi Kepuasan Pelanggan Dalam Bisnis Online.

Sugiyono. (2017). Metode Penelitian Bisnis: Pendekatan Kuantitatif, Kualitatif, Kombinasi, dan $R \& D$. Bandung: Alfabeta.

Syaifuddin (2017). Pengaruh Sosial. Pada Universitas Negeri Yogyakarta: http://journal.student.uny.ac.id/ojs/in dex.php/profita/article/view/9764

Triatmaja \& Yuliana (2016). Pengaruh Perceived Value dan Sosial Influence Terhadap Purchase Intention Smartphone $4 G$ Pada Pelanggan Bandung Elektronic Center. Pada Universitas Telkom Bandung: https://id.scribd.com/document 